\title{
The senior year students' persistence profile of UMTAS (University of Muhammadiyah Tasikmalaya)
}

\section{Aditia Luanda*}

Faculty of Education, University of Muhammadiyah Tasikmalaya email: luandaaditia@gmail.com

\section{Feida Noor Laila Isti'adah}

Faculty of Education, University of Muhammadiyah Tasikmalaya email: feida@umtas.ac.id

\section{Agung Nugraha}

Faculty of Education, University of Muhammadiyah Tasikmalaya email: agung.nugraha@umtas.ac.id

Received: September 24, 2020; Revised: October 05, 2020; Accepted: October 16, 2020

\begin{abstract}
This study aims to determine the profile of senior year students at the end of class 2015 that have been studied for 4 years or undergraduate students (S1). This descriptive study was conducted to 10 study programs (S1) at the University of Muhammadiyah Tasikmalaya with a sample number of 142 students. Measuring instrument employed in the form of a questionnaire multiple choice that refers to the grand theory of Pury (Lopez, 2009), which was designed by the researcher in 2019. The results revealed that the persistence of 2015 students was in high category with a percentage of $77.33 \%$. The number of final-level students in the high category of $85 \%$ or 121 students, in addition there were $14 \%$ or 20 students who belonged to the medium category and $1 \%$ or 1 student was in the low category. This indicates that in general, the senior students at the Universitas Muhammadiyah Tasikmalaya have demonstrated maximum persistence in each dimension, including having high desire and awareness to pursue their goals, doing hard effort sustainably, instilling persistent character in resolving the problems, as well as the students can survive and move forward despite the challenges and difficulties in achieving their objectives.
\end{abstract}

Keywords: persistence, student of university

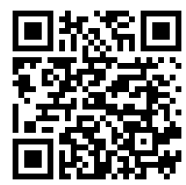

This is an open-access article under the CC-BY-SA license.

\section{Introduction}

Students are required to complete their studies on time, in achieving that, students get a variety of obstacles or problems, starting from research and personal characters problems. The research problems such as ranging from rejecting the title of research, preparing difficult instruments, being difficult to contact the supervisors, getting different supervisors' views, revising final paper repeatedly, having limited references and ability to write research. Besides, the personal characters problems for example, having problems to end the assignments, enjoying 
laziness and confusion, being fear of criticism, giving up easily, and being lack of time management, motivation and discipline.

Regarding to obstacles or problems mentioned, in the field of psychology, being lack of time management or discipline is known as procrastination. 'Procrastination is one of the behaviors that are inefficient to use time and there is a tendency to not start working immediately to do the task (Ghufron, cited in Irawati, 2013). This is confirmed by Mugiarso (2018, p.171), he claims that students who do not have high persistence can experience procrastination, even fails to complete the final project or success in academic program, social development and getting proper job (Istia'dah, 2018,p.7). Based on the problems found in his research, it is categorized as lack of persistence. We define persistence as voluntary continuation of a goal-directed action in spite of obstacles, difficulties, or discouragement (Peterson, 2004, p.229).

Therefore, they need to realize that the character of persistence is really needed to deal with problems or challenges and achieving goals, especially the final year students. These statements are proved by the results of the interview which was done by the final year students (S1) of University of Muhammadiyah Tasikmalaya 2019.

The importance of students' persistence is highlighted by Palila (2016, p.117); she claims that there are three characters needed by students such as persistence, empathy and self-regulation. In line with Palila, Brown et al (Wright, 2012, p.296) states that University students' persistence determines academic success. In addition, the students of science, technology, engineering, and mathematic (STEM) assume that high and positive persistence will support leaning process quality to increase the quality of graduate (Zamista, 2017, p.23).

Persistence tends to be faced by adult. Final year students are in the adult development stage, it means that they have a new pattern to be more independent and have a commitment. Thus, it will help them to survive and solve their own problems, especially when they work hard to achieve their goals persistently (Hulukati, 2016, p.2).

Results on persistence indicate that learning strategies and motivation have amoderate explanatory value regarding academic success and persistence, and that these effects remain even after controlling forthe influence of background variables (Vanthournout, gert et al, 2012, p.2).

Hill (2007, p.151) declares that persistence is an important factor to turn desire into reality. The facts of the observations conduct that students' persistence is needed. If students' persistence is not optimal, it will show the students' failure in completing the final project. Therefore, it can affect the achievement of the goals of graduate on time. The urgency of students' persistence made the researcher realize that the persistence study of the university need to be investigated as a basic picture to examine the variable of persistence in higher education.

\section{Method}

The study aimed to describe the real condition of senior year students' persistence of Muhammadiyah Tasikmalaya University. Hence, the study employed quantitative approach through descriptive method. This descriptive research was intended to find facts, condition and current phenomenon and portray the reality of the condition (Subana, 2005, p.15).

Regarding to the explanation above, this study conducted general description or persistence profile of undergraduate students at the end of class 2015 in Muhammadiyah Tasikmalaya by using persistence questionnaire multiple choice based on Puri (Lopez, 2019). In addition, the questionnaire was formulated by the researcher of this study to show clear description of the persistence condition in each category such as high, medium and low based on statistic calculation. 
Table 1. The persistence instrument in this study can be shown as follows

\begin{tabular}{|c|c|c|c|c|c|}
\hline \multirow[t]{2}{*}{ Dimensions } & \multirow{2}{*}{\multicolumn{2}{|c|}{ Indicator }} & \multicolumn{2}{|c|}{ Statement Items } & \multirow[t]{2}{*}{$\sum$} \\
\hline & & & $(+)$ & $(-)$ & \\
\hline \multirow[t]{2}{*}{$\begin{array}{l}\text { Intentional and goal- } \\
\text { directed }\end{array}$} & (1) & $\begin{array}{l}\text { Having clear } \\
\text { objective. }\end{array}$ & $1,2,3,4,5$ & $\begin{array}{l}39,40,41,4 \\
2,43\end{array}$ & 10 \\
\hline & (2) & $\begin{array}{l}\text { Having personal } \\
\text { desire/intention }\end{array}$ & $6,7,8,9$ & $\begin{array}{l}44,45,46,4 \\
7,48\end{array}$ & 9 \\
\hline \multirow[t]{3}{*}{$\begin{array}{l}\text { Continuation atau } \\
\text { reapplication to effort }\end{array}$} & (1) & $\begin{array}{l}\text { Having } \\
\text { sustainable self- } \\
\text { confidence }\end{array}$ & $\begin{array}{l}10,11,12,1 \\
3\end{array}$ & $\begin{array}{l}49,50,51,5 \\
2\end{array}$ & 8 \\
\hline & (2) & $\begin{array}{l}\text { Having } \\
\text { organized } \\
\text { planning }\end{array}$ & $\begin{array}{l}14,15,16,1 \\
7,18\end{array}$ & $53,54,55$ & 8 \\
\hline & (3) & $\begin{array}{l}\text { Doing } \\
\text { sustainable effort }\end{array}$ & $\begin{array}{l}19,20,21,2 \\
2,23\end{array}$ & $\begin{array}{l}56,57,58,5 \\
9,60\end{array}$ & 10 \\
\hline \multirow[t]{4}{*}{ Templation to quit } & (1) & $\begin{array}{l}\text { having } \\
\text { Cooperative } \\
\text { behavior } \\
\text { resolving } \\
\text { problem }\end{array}$ & $\begin{array}{l}24,25,26,2 \\
7,28\end{array}$ & $\begin{array}{l}61,62,63,6 \\
4,65\end{array}$ & 10 \\
\hline & (2) & $\begin{array}{l}\text { Having strong } \\
\text { determination to } \\
\text { be better }\end{array}$ & $\begin{array}{l}29,30,31,3 \\
2,33\end{array}$ & $\begin{array}{l}66,67,68,6 \\
9,70\end{array}$ & 10 \\
\hline & & $\begin{array}{l}\text { Taking persistent } \\
\text { to be a good } \\
\text { habit }\end{array}$ & $\begin{array}{l}34,35,36,3 \\
7,38\end{array}$ & $\begin{array}{l}71,72,73,7 \\
4\end{array}$ & 9 \\
\hline & & Total & & & 74 \\
\hline
\end{tabular}

The validity test uses Pearson Product Moment, the results of the validity test are then processed using the SPSS computer program and obtained 74 valid instruments. In addition, based on the results that have been obtained from the reliability test using SPSS 16, it can be revealed in the following table: 


\section{Reliability Statistics}

\begin{tabular}{rrr}
\hline $\begin{array}{c}\text { Cronbach's } \\
\text { Alpha }\end{array}$ & $\begin{array}{l}\text { Cronbach's Alpha Based } \\
\text { on Standardized Items }\end{array}$ & N of Items \\
\hline .969 & .970 & 74 \\
\hline
\end{tabular}

\section{Findings and Discussion}

The general description of students' persistence was obtained from the instrument of persistence at the end of 2015 class students at the University of Muhammadiyah Tasikmalaya which is a sample of 10 study programs that have studied for 4 years or undergraduate student (S1). The result and discussion on the persistence will be shown as follows;

\section{Findings}

The persistence's profile of Muhammadiyah Tasikmalaya University students showed high persistence category as the table illustrated below;

Table 4.1. The profile of persistence in the final year (S1) Universitas Muhammadiyah

\begin{tabular}{ccccc}
\multicolumn{5}{c}{ Tasikmalaya } \\
\hline Range & Category & Frequent & Presentage (\%) & Average \\
\hline $0-123$ & Low & 1 & $0.70 \%$ & \\
$124-246$ & Medium & 20 & $14.08 \%$ & $77.33 \%$ \\
$247-370$ & High & 121 & $85.21 \%$ & \\
\hline
\end{tabular}

The following results from the persistence profile table will be visualized in graph 4.1 below;

Graph 4.1. Overview of students' persistence dimensions and indicators

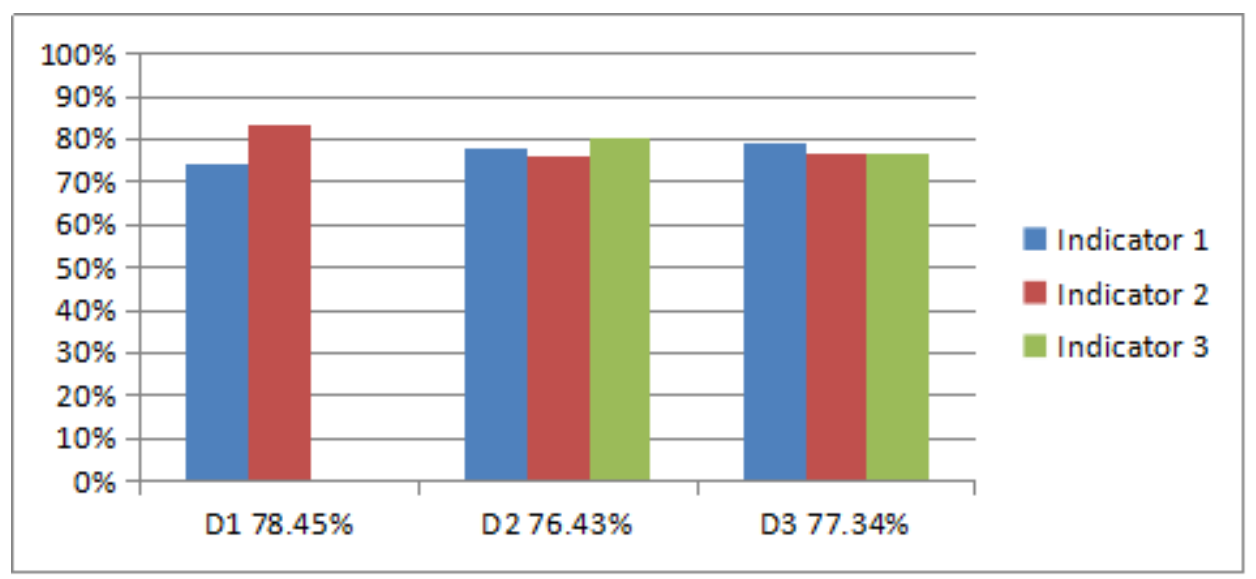

Following is the detail description of the dimensions and indicators of persistence. 
Table 4.2. General overview of students' persistence indicators

\begin{tabular}{|c|c|c|c|c|}
\hline No & Dimension & Indicator & Mean & Stdv \\
\hline \multirow[t]{2}{*}{1} & Intentional and & Having clear objective & 37.10 & 5.59 \\
\hline & goal-directed & $\begin{array}{l}\text { Having personal } \\
\text { desire/intention }\end{array}$ & 37.52 & 5.64 \\
\hline \multirow[t]{3}{*}{2} & $\begin{array}{l}\text { Continuation or } \\
\text { reapplication to }\end{array}$ & $\begin{array}{l}\text { Having sustainable } \\
\text { self-confidence }\end{array}$ & 31.07 & 5.42 \\
\hline & & Having organized planning & 30.28 & 5.42 \\
\hline & & Doing sustainable effort & 37.93 & 6.36 \\
\hline \multirow[t]{3}{*}{3} & $\begin{array}{l}\text { Templation } \\
\text { quit }\end{array}$ & $\begin{array}{l}\text { Having Cooperative behavior } \\
\text { in resolving problem }\end{array}$ & 39.42 & 5.51 \\
\hline & & $\begin{array}{l}\text { Having strong } \\
\text { determination to be better }\end{array}$ & 38.26 & 6.03 \\
\hline & & $\begin{array}{l}\text { Making persistent to be a } \\
\text { good habit }\end{array}$ & 34.47 & 5.46 \\
\hline
\end{tabular}

In line with these high categories, the final year students have shown their perseverance by having a high desire and awareness to pursue their goals, making a sustained endeavor and instilling persistent character to solve their problems.

\section{Discussion}

The results of the research presented a general picture of persistence in the final year (S1) students of the University of Muhammadiyah Tasikmalaya class of 2015 is in the high category with a percentage of $77.33 \%$. Based on these high categories, in general the final year students have shown their perseverance by having a high desire and awareness to pursue their goals, making a sustained endeavor and instilling persistent character to solve their problems.

In addition, final year students attained their persistent because they could survive and moved forward despite experiencing various challenges and difficulties in achieving their goals. In line with the task of student development of the task of adult or autonomous development, Koestner (Peterson, 2004, p.236) reveals that people who have high autonomy can survive from the failure longer than others. These results are in accordance with the persistence profile or the persistence of final year (S1) students at Muhammadiyah University, Tasikmalaya, which had mostly shown high persistence category.

Furthermore, these results are in accordance with the reality experienced by students at the end of the class of 2015, most students have completed their final assignment without failure. This situation was also strengthened by several factors who were analyzed, such as they belonged to the first batch at the University of Muhammadiyah Tasikmalaya. It means that the students had completed each lecturer programmed until finish doing their final task or final paper. Having high social support from every teaching staff in each study program can influence students' persistence. Besides, the number of Student Activity Units (UKM) built good relationships among students from different study programs. In addition, the persistence of students arose from some social support from outside the study program at the University of Muhmmadiyah Tasikmalaya. Therefore, it encourage positive feedback on each student to develop and survive in achieving their goals, as well as every student effort and hard work.

Several studies related to persistence according to (Lopez,2009) include the self-efficacy variable. Individuals who are higher in self-efficacy have shown increased persistence on a variety of tasks. Furthermore self-esteem, or self-worth, also influences persistence. in situations where persistence tends to lead to eventual success, individuals with high self-esteem show more persistence than those with low self-esteem. 
The high tenacity of these students can also be strengthened by Andrew (Peterson, 2004, p.21) which reveals that persistence factors include;

1. Effortful Behavior

Individuals who experience a history of getting rewards for their past behavior have greater effort in the future.

2. Social Support

Social support provides individuals to increase persistence. Zaleksi (Peterson, 2004, p.241) claims that individuals who have close and supportive relationships are more able to persist and exert more effort than individuals who do not have close and supportive relationships. Madhlangobe (2014, p.14) adds that the level of social support from the university or support from outside the university such as family, friends, and mentors can be the center of the level of persistence shown by individuals).

3. Feedback

Positive feedback contributes to increase persistence. Kalley, et al (Peterson, 2004, p.241) shows that when mothers give positive and corrective feedback to their 2-year-old children, the child lasts longer in doing easy or difficult tasks.

Advantages and positive feedback are not completely uniform. Paul and Konick declare that negative evaluations from other people led individuals to be more persistent in their work than positive evaluations or without evaluations. Children who were praised for their intellectual abilities after the first failure were less persistent and did not enjoy the tasks assigned to them more than children who were praised for their efforts (Mueller, cited inPeterson, 2004, p.245).

The category of high persistence in this final year student can be interpreted that students have achieved maximum persistence in several dimensions and indicators, the following can describe persistence dimensions according to Pury (Lopez, 2009, p.678-679):

1. Most of the students have a high awareness to pursue their desired goals. This is in line with the results of observations of the final year students, especially on the fulfillment their final project to be a complex phenomenon to instill persistence in the final level students. These results indicate that most students were aware of the objectives that had to be done and to be done namely completing the final project. Besides, there were several examples of persistence behavior shown by the final year students in pursuing their goals by consulting with other students in the study program or outside the study program. Moreover, consulting with the guardian lecturer as well as with the supervisor were important aspects.

2. Most of the students show and do hard work repeatedly. The effort was carried out by every student in carrying out various kinds of tasks. The findings were in accordance with actual field phenomena, but the rigors of the end-level student's efforts could still be improved again, as evidenced in the results of the study revealing that the second dimension (Continuation or Reapplication Effort) reached a percentage score of $76.43 \%$ as well as being the smallest dimension of the other dimensions. This was consistent with the phenomenon in the field that some of the final year students had different efforts in achieving their goals. This could be seen from the many students who had finished their final project and some other students had experienced failure in the context of completing their final project, this phenomenon occurred due to the different learning systems in each study program, the needs of each study program and various existing faculties at the Muhammadiyah University of Tasikmalaya.

3. Most students have persistent character in overcoming obstacles that will occur. The findings in the field illustrate that the final year class of students who had taken lectures for 4 years or had a bachelor degree achieved high persistence. In addition, the persistent character showed several complex problems in line with the preliminary study that students experienced various problems related to the completion of the final project, including getting difficult to find titles, revising the paper recently, having problems to understand the research, being fear to be criticized, being fear of failure, being confused, and showing other 
complex problems. Based on the findings of persistence at the University of Muhammadiyah Tasikmalaya and the phenomenon of the real field, some students of the class of 2015 tended to survive in completing their final assignments. It was shown by final paper contract that has been done.

In line with Meyer's research (Peterson, 2004, p.231) which shows that people who consider themselves to have a high ability to persistence (persistence) tend to last longer than others on easy and difficult tasks, recent research shows that persistence may depend on self-control. Some of this research has found that people tended to stick to difficult or inconvenient problems, if they had used self-control in previous tasks, such as trying to control their thoughts and emotions or resist the temptation to eat chocolate and cakes (Muraven, et al in Peterson, 2004, p.234). Some evidence shows that the capacity for self-control is enhanced by positive emotions such as a good mood that will sustain or work harder to complete tasks (Kavanagh, in Peterson, 2004, p.234). From all the statements, these findings also show that perseverance of failure is relatively difficult and people tend to give up and turn their attention elsewhere.

The strength of persistence does not describe the development of steps in individual differences, but various factors of personality and other individual differences. Ability is a persistent individual difference. With persistent abilities, individuals must be willing to keep doing tasks at least according to their abilities. Based on this argument, it can be interpreted that people with high abilities have high expectations for ultimate success. According to Feather (Peterson, 2004, p.235) reveals that people have a strong motivational orientation towards more control and mastery to survive, maybe because they are encouraged to master the task successfully and put a lot of time and effort into achieving that success.

In addition, individuals who have a high persistence or persistence can be characterized by individuals who have resilience and have a sense of commitment to their lives (Peterson, 2004, p.236), the statement is in accordance with the task of development in the research sample that is the final year students who have found a new pattern to be more independent and have a commitment to the problem so that it will help in making students survive and solve the problems being faced.

According Sunaryo (Yusuf dan Juntika, 2008) the development of students in tertiary institutions is in the autonomous category which has the following characteristics.

1) Having a view of life as a whole;

2) Leaning to be realistic and objective towards oneself and others;

3) Caring about abstract understanding such as justice;

4) Being able to integrate conflicting values;

5) Caring for self-fulfillment;

6) Empowering to resolve conflicts;

7) Respecting for the independence of others;

8) Being aware of interdependence with others;

9) Being able to express feelings with confidence and joy.

These developmental tasks are in line with the category characteristics of persistence. Koestner (Peterson, 2004, p.236) reveals that people who have high autonomy tend to survive longer from failure than others. These results are in accordance with the persistence profile or the persistence of final year (S1) students at Muhammadiyah University Tasikmalaya, which are mostly in the high persistence category. Although the persistence of students is high, the effort to achieve maximum persistence can be influenced by desire or hope, self confidence, self esteem or self-assessment and the commitment of each individual (lopez,2009).

\section{Conclusions}

There are variations in the level of persistence in the final year (S1) students of the Muhammadiyah University of Tasikmalaya class of 2015. The variation is theoretically caused by the research subjects which have different attitudes and views on the indicators in the form of 
persistence questionnaires at the final year students in line with each research subject in adapting their suitability or state of the existing indicators. Some of these variations are shown in the results of the percentage score in each dimension with a percentage score of $78.54 \%$ in the Intentional and goal directed dimensions which are in the high category on the indicator of having an inner desire, a percentage score of $77.34 \%$ in the dimension of templation to quit which is at the high category on the indicator has a cooperative attitude in dealing with the problem, and $76.43 \%$ in the dimension of continuation or reapplication effort which is in the high category on the indicator of doing a sustainable business. Regarding to the results of the persistence profile of students at the end of the study program (S1) at the University of Muhammadiyah Tasikmalaya, the highest percentage score was in the PTI study program with an actual average of $84.50 \%$ belonged to high tenacity category. In addition, the lowest percentage score obtained by environmental engineering with a percentage of $68.90 \%$.

\section{Recommendations}

Persistence is the strength of character proposed by Andrew C. Harter (Peterson, 2004, p.229). According to the dictionary, persistence means "to persevere" or "to repeat". It means that something is happening but certain characteristics remain or remain unchanged, even in the face of stress. The following recommendation in this study refer to guidance and counseling practitioners and to further researchers.

1. For Guidance and Counseling Practitioners

a. Guidance and counseling practitioners should thoroughly ensure the research result of persistence profile of final year students who are the first year on the campus of the University of Muhammadiyah Tasikmalaya to be validated, and measure the persistence of students from each study program at the Muhammadiyah University of Tasikmalaya.

b. Guidance and counseling practitioners should be able to provide guidance and counseling services related to student persistence based on the "Need Assessment" in each class to improve the fulfillment of student assignments related to achieving goals.

c. Creating a consultation service for all students at the University of Muhammadiyah Tasikmalaya who have problems academic and non-academic problems.

d. Adding teaching staff (lecturers) in each study program that has a lot of student ratios, including in the Guidance and Counseling study program.

2. For Further Researchers

Based on the results of research conducted, there are several recommendations that can be done by subsequent researchers;

a. The character of persistence is not only needed by final year students, but this persistence is needed by elementary, junior high, high school and college students. Therefore, it is necessary to conduct research and the provision of services such as Guidance and Counseling services to increase persistence based on need assessment.

b. Future studies are expected to look for other variables related to persistence or formulate determinant factors that can affect the character of persistence in tertiary institutions, as well as at elementary, junior high and high school levels.

\section{References}

Brown, S. D., Tramayne, S., Hoxha, D., Telander, K., Fan, X., \& Lent, R. W. (2008). 'Social cognitive predictors of college students' academic performance and persistence: A metaanalytic path analysis'. Journal of Vocational Behavior, 72, 298-308.

Hill, Napoleon. (2019). Think and grow rich. Jakarta : Bhuana Ilmu Populer.

Irawati. (2013). NN. Diakses pada tanggal 10 Mei 2019. Tersedia di : http://eprints.ums.ac.id/24521/2/04._BAB_I.pdf.

Isti'adah, Feida N.L.(2018). Komparasi self regulated learning pada mahasiswa yang bekerja dan tidak bekerja. Journal of InnovativeCounseling :Theory, Practice \& Research, 3(1):pp.1-5. 
Lopez, Shane J. (2009). The encyclopedia positive psychology. Blacwell Publishing Ltd. ISBN: 978-1-405-16125-1.

Mugiarso, Heru., et al. (2018). 'Self-Efficacy dan Persistence Mahasiswa Ketika Mengerjakan Skripsi Ditinjau dari Kecemasan Akademik'. Jurnal Bimbingan dan Konseling, 1 (3), 171-175. Diakses pada tanggal 26 Oktober 2018 [online]. Tersedia di : https://www.researchgate.net/publication/323940700_Self-

efficacy_dan_persistensi_mahasiswa_ketika_mengerjakan_skripsi_ditinjau_dari_kecema san_akademik.

Palila, Sara. (2016). Analisis kebutuhan karakter mahasiswa psikologi fakultas ilmu sosial dan humaniora UIN Sunan Kalijaga Yogyakarta. Diakses pada tanggal 12 Januari 2019 [online]. Tersedia di http://journal.uad.ac.id/index.php/HUMANITAS/article/view/3838.

Peterson, C., Seligman, M. E. P. (2004). Character strengths and virtues : A Hanbook and Classification. New York: Oxford University Press.

Vanthournout, gert et al, (2012). Students' Persistence and Academic Success in a First-Year-Professional Bachelor Program: The Influence of Student's Learning Strategies and Academic Motivation. Education Research International Volume 2012, Article ID 152747, 10 pages.

Wright, S. L., Jenkins-Guarnieri, M. A., \& Murdock, J. L.. (2012). Career Development, 40(4), 292-310.

Zamista, Adelia Alfama. (2017). Increasing persistence of collage student in science technology engineering and mathematic (STEM). Journal of Teachimh and Learning Vol 3 No 12018. 